\title{
IBM DHARMA WANITA PERSATUAN KOTA SEMARANG
}

\author{
Karis Widyatmoko ${ }^{1}$, Desi Purwanti $K^{2}$ \\ Universitas Dian Nuswantoro \\ J1. Nakula I/5-11, Semarang 50131 \\ Telp. (024) 3517261, Faks. (024) 3569684 \\ E-mail: ${ }^{1}$ kariswidyatmoko@gmail.com, ${ }^{2}$ d7_pk@yahoo.com
}

\begin{abstract}
Abstrak
Musik gamelan merupakan musik orkestra yang merupakan warisan Bangsa Indonesia. Nilai-nilai luhur yang merupakan warisan budaya perlu dilestarikan oleh generasi muda. Kurangnya apresiasi generasi muda terhadap musik gamelan disebabkan oleh kurangnya ketersediaan media pembelajaran. Tipikal musik orkestra dalam hal ini musik gamelan yang mahal, dan memerlukan ruangan besar menjadi faktor penyebab kurangnya ketersediaan media untuk belajar.Egamelanku merupakan aplikasi yang dapat menjadi solusi untuk belajar mengenal, dan memainkan instrumen musik gamelan..

Dharma Wanita Persatuan (DWP) Kota Semarang merupakan organisasi yang aktif dalam pendidikan, ekonomi, dan sosial budaya. Anggota DWP Kota Semarang merasa perlu untuk dapat belajar memainkan musik gamelan. Program pelatihan dan pendampingan egamelanku menjadi pilihan DWP Kota Semarang sebagai sarana belajar untuk mengenal dan memainkan musik gamelan sebagai upaya untuk melestarikan warisan budaya Bangsa Indonesia.
\end{abstract}

Kata kunci: egamelanku

\section{PENDAHULUAN}

Musik gamelan merupakan musik orkestra tradisional dari Jawa yang menggunakan gamelan sebagai instrumen. Musik orkestra memiliki tantangan dalam penyelenggaraannya yaitu berbiaya mahal, memerlukan ruangan besar, dibagi dalam beberapa seksi berdasarkan klasifikasi instrumen, dan membutuhkan waktu bertahun-tahun untuk menguasai instrumen [1]. Tantangan dan kendala dalam penyelenggaraan musik orkestra, dalam hal ini musik gamelan, menyebabkan akses untuk mempelajarinya menjadi sulit.

Musik gamelan merupakan warisan luhur Bangsa Indonesia. Masyarakat terutama generasi muda memiliki tanggung jawab untuk melestarikan budaya yang memiliki nilai-nilai luhur kebudayaan. Penelitian yang dilakukan oleh Tyas [2] menyebutkan bahwa generasi muda cenderung kurang memberikan apresiasi terhadap musik gamelan. Survei tentang gamelan yang diselenggarakan oleh Pramudi et al [3] menyebutkan bahwa, 66,7\% siswa SMA di Jawa Tengah tidak pernah belajar gamelan, dan $76,7 \%$ tidak bisa menabuh gamelan. Kondisi ini memerlukan langkah-langkah strategis untuk menjaga kelestarian musik gamelan sebagai warisan budaya nasional. Sejauh ini, telah diupayakan inovasi untuk menjaga kelestarian gamelan, yang salah satunya berbasis teknologi informasi. Penerapan teknologi informasi mentransformasi gamelan ke dalam format virtual, yaitu dengan memanfaatkan perangkat komputer atau mobile sebagai media untuk memainkan instrumen gamelan.

Program aplikasi gamelan virtual, seperti e-Gamelanku memungkinkan pengguna memainkan instrumen gamelan melalui komputer, atau perangkat bergerak seperti smart phone atau tablet. Egamelanku memudahkan masyarakat untuk belajar mengenal instumen gamelan, dan memainkannya. 
Dharma Wanita Persatuan (DWP) Kota Semarang [4] merupakan organisasi yang aktif dalam bidang pendidikan, ekonomi, dan sosial budaya. Anggota DWP Kota Semarang merasa perlu untuk melestarikan warisan budaya salah satunya adalah gamelan. Perangkat gamelan yang mahal dan membutuhkan ruangan yang besar merupakan kendala bagi DWP Kota Semarang untuk dapat mengenal, dan memainkan instrumen gamelan. Anggota DWP Kota Semarang telah menggunakan smartphone dalam aktivitas kesehariannya sehingga Egamelanku dipilih sebagai solusi bagi DWP Kota Semarang untuk dapat mengenal berbagai instrumen gamelan, cara memainkan baik mandiri, maupun secara orkestra.

\section{METODE PENELITIAN}

Tahapan kegiatan dalam pelatihan, dan pendampingan e-gamelanku adalah sebagai berikut:

1. Analisis masalah dan solusi: pada tahap ini, permasalahan dan kebutuhan dari pengguna dianaliasis untuk mengetahui tingkat pemahaman pengguna tentang instrumen dalam musik gamelan, dan cara memainkan.

2. Pelatihan dan pedampingan: pada tahap ini, mitra diberikan pelatihan dalam mengoperasikan eGamelanKu melalui perangkat smartphone. Anggota DWP Kota Semarang dikenalkan dengan berbagai jenis instrumen gamelan, dan cara memainkannya. Anggota DWP Kota Semarang diberikan pendampingan ketika memainkan instrumen gamelan secara orkestra, lengkap dengan sinden, dan memberikan umpan balik terhadap keberhasilan pengguna dalam memainkan egamelanku.

Umpan balik: umpan balik dilakukan pada akhir tahapan. Hal ini dimaksudkan untuk mengidentifikasi jika masih terdapat kekurangan dan kelemahan pengguna dalam memainkan aplikasi egamelanku.

\subsection{Analisis Masalah dan Solusi}

Masalah yang dihadapi DWP Kota Semarang dianalisis dengan membentuk Focus group discussion (FGD), sehingga dapat diketahui tingkat pemahaman pengguna tentang instrumen musik gamelan, dan cara memainkannya. Anggota DWP Kota Semarang mengenal gamelan sebatas tau sebagai alat musik warisan Bangsa Indonesia, belum pernah mengenal jenis instrumen musik gamelan, tidak mengetahui bunyi yang dihasilkan secara khusus masing-masing instrumen kecuali gong, dan kendhang, serta cara memainkannya.

Anggota DWP Kota Semarang menggunakan smartphone dalam aktivitas kesehariannya sehingga tidak gagap menggunakan perangkat smartphone untuk menjalankan aplikasi egamelan.

\subsection{Pelatihan dan pendampingan}

Pada tahap ini, tim pengusul memberikan pelatihan berupa materi tentang pengenalan instrumen gamelan, jenis laras dalam gamelan yaitu Slaras Slendro dan pelog, bunyi yang dihasilkan tiap instrumen, cara memainkan instrumen gamelan, cara mengunduh aplikasi egamelan, cara menjalankan aplikasi egamelan, memainkan tiap instrumen gamelan melalui aplikasi, dan memainkan instrumen secara orkestra. Instrumen yang digunakan adalah gong, demung, saron, peking, bonang barung, bonang penerus, kethuk kempyang, kenong, dan slenthem. Anggota DWP Kota Semarang juga diberikan pelatihan singkat untuk dapat menyajikan lagu Jawa yang cukup familiar, dan mudah dimainkan. 

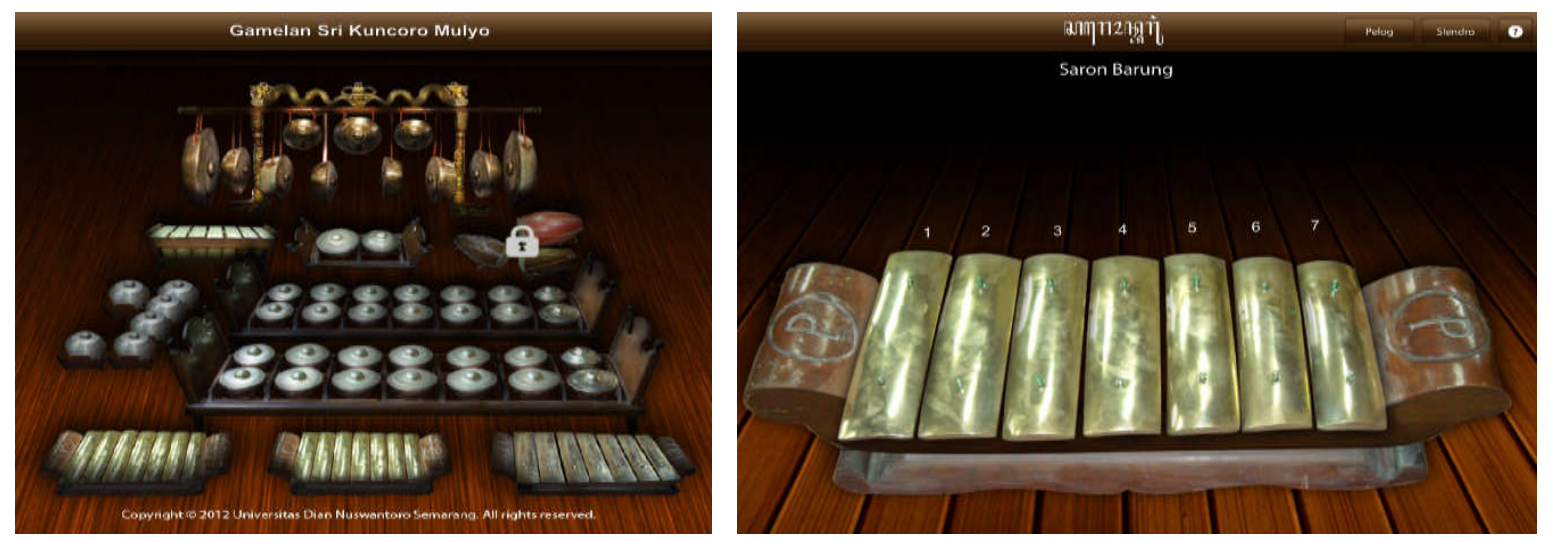

Gambar 1. Screenshot program

Umpan balik dilakukan untuk mengidentifikasi jika masih terdapat kekurangan dan kelemahan pengguna dalam memainkan aplikasi egamelanku.

\section{HASIL DAN PEMBAHASAN}

IbM pada Dharma Wanita Persatuan Kota Semarang memiliki capaian maksimal dalam pelaksanaan pelatihan dalam rangka penggunaan aplikasi egamelanku. Aktivitas pelatihan dan pendampingan ditunjukkan dalam tabel 1 .

\section{Tabel 1. Capaian Hasil Kegiatan IbM pada Dharma Wanita Kota Semarang}

\begin{tabular}{lll}
\hline No & Kegiatan & Capaian \\
\hline \hline 1 & Pelatihan & $100 \%$ \\
& pengenalan & \\
& instrumen gamelan, \\
& dan cara memainkan \\
& instrumen secara \\
& mandiri & \\
2 & $100 \%$ \\
& $\begin{array}{l}\text { Penggunaan aplikasi } \\
\text { egamelanku }\end{array}$ \\
\hline
\end{tabular}

\section{KESIMPULAN}

DWP Kota Semarang yang merupakan mitra dalam program ini dapat memanfaatkan aplikasi egamelanku sebagai sarana pembelajaran untuk mengenal instrumen gamelan, cara memainkan musik gamelan, dan mampu memainkan dan menyajikannya secara orkestra, dan mampu untuk mengoperasikan egamalanku secara mandiri. 


\section{DAFTAR PUSTAKA}

[1] D. Trueman, Why a Laptop Orchestra, Cambridge Journal Volume 12, 2007.

[2] Pramudi, Tyas., Model Pembelajaran Multimedia Seni Gamelan Jawa, Riptek, Vol. 4, No. $1,2010$.

[3] Pramudi, Tyas., Budiman, Fikri., Sunardi, Desain Virtual Gamelan Jawa sebagai Media Pembelajaran, Seminar Nasional Aplikasi Teknologi Informasi, 2010.

[4] http://seputarsemarang.com/dharma-wanita-persatuan-10564/ diakses tanggal 10 Januari 2018. 